examination precedes the systematic account, which is provided with the usual keys and with illustrations to facilitate identification and to show structural features. The illustrations are for the most part satisfactory, but the author's photograph of a much distorted transverse section of Parascaris equorum could have been omitted. The memoir will be helpful to those who are interested in the helminths of Indian domestic animals. It is marred by a considerable number of misprints which necessitated the addition of a slip correcting more than fifty errata. One of these is "for Linneas read Linnaes" and on reference to the page cited we find "Linneas 1858" which should, of course, be "Linnaeus, 1758" ; more care in reading the proof would have been well repaid in the result.

\section{Fungi of South Australia}

THE South Australian Branch of the British Science Guild is making a determined effort to interpret the flora and fauna of the southern parts of Australia to students of biology in that region. It has on one hand the sympathy and active financial support of the South Australian Government, and on the other hand the authors of a series of handbooks, who propare their manuscripts gratuitously. The latest volume to be added to this list is the second part of "Toadstools and Mushrooms and other Larger Fungi of South Australia" (Adelaide : Govt. Printer. 5s. net. Pp. 177-362. June 1935). Prof. J. B. Cleland, who is also chairman of the Committee responsible for the handbooks, has written the volume, which deals with polyporous and coral fungi, with puff-balls, jelly-like fungi, and the larger Ascomycetes and Myxomycetes. The volume forms, with Part 1 (published in June 1934), a complete guide to the grosser fungi of the area mentioned in the title, and it is no fault of the author that the Hymenomycetes are in great preponderance. Ascomycetes receive somewhat scant treatment upon five pages, whilst Myxomycetes receive slightly less, but the treatment of the Basidiomycetes should make the volume into a mycological classic. The classification adopted is a combination of the systems propounded by Carleton Rea and P. Claussen. It is easy to follow, though a purely English reader might have preferred to see either the modern thoroughness and authoritative dignity of Rea, or the comprehensive well-tried simplicity of Claussen, adopted throughout.

\section{Aims and Methods of Medical Science}

THIs was the title of the inaugural lecture delivered on November 26 by Prof. John Ryle, the new regius professor of physic at Cambridge, and now available in attractive book-form (Cambridge University Press, 1935, 2s, net). Prof, Ryle reviews the scope and present shortcomings of medical science, and concludes that among the great body of practitioners and laboratory workers there is too large a.proportion whose standards of accuracy are defective, and whose judgment is crippled. These shortcomings are ascribed to three primary errors : (1) faulty selection of men, or misdirection of their energies after quali fication; (2) complicated and unwieldy systems of education and examination; and (3) the spread of the cult of specialism. Prof. Ryle does not condemn specialism as such, "for good specialism is essential to all scientific progress"; but condemns only excessive, premature and misdirected specialisms for the subversive influences which they have had upon medical thought, action and education. In seeking a remedy, Prof. Ryle reviews some of the recent achievements in medicine, and finds that the clinician has himself exporimented, or that there has been intimate collaboration between experimonter and clinician. Observation and experiment are both essential, but they must go hand in hand. Prof. Ryle envisages that in the future the younger men will turn more frequently to the study of problem: at the bedside, and that a happier partition of problems and a closer collaboration between the wards and the laboratory, between students of normal and students of morbid physiology, than obtains at present, will play their part.

\section{Report of the Rockefeller Foundation}

According to the annual report which has recently been published, the Rockefoller Foundation expended $12,679,775$ dollars during the year 1934. In public health, field researches were undertaken on yellow fever, malaria, hookworm disease, tubereilosis and several other diseases, and the organisation and maintenance of essential State and national hoalth services in various parts of the world were promoted. In the medical sciences, many university department: and others received aid for psychiatry, and the Lister Institute funds for the purchase of an ultracentrifuge. In the natural sciences, grants were made for promoting experimental biology and genotics, physiology and endocrinology. In the social scionces, the largest grant went to the Welfare Council of New York City, and several universities, including Oxford, and other bodies, received support. In the humanities, grants supplementing former assistance were made to the Bodleian Library and the Bibliothè yue National, in Paris, and the Foundation appropriated funds for the "Dictionary of American Biography", the "Historical Dictionary of American English", and the "Virginia Historical Index"-works now in course of preparation.

\section{Reports of the Smithsonian Institution, Washinzton}

THE annual reports for 1933 and 1934 of the Smithsonian Institution of Washington, both of which have recently been received, give details of the operations and expenditures during the sessions in question (Superintendent of Documents, Washington, D.C. I dollar). In both volumes, reports are given summarising the year's activities, finances, grants, publications, library, etc. These are followed by detailed reports which include those of the Bureau of American Ethnology, National Zoological Park, Astrophysical Observatory, Division of Radiation and Organisms, International Catalogue of Scientific Literature and the International Exchange Sorvice. The greater part of each volume is, however, usod 